\title{
Experimental Determination of Heat Transfer using a Polymer Solution Shower during Induction Hardening*
} Experimentelle Bestimmung des Wärmeübergangs für Brausenabschreckung mit Polymerlösung beim Induktionshärten

\section{Abstract/Kurzfassung}

Heat treatment simulation of inductive surface hardening of large bearing rings is a challenging multi-physical task. Besides the determination of material and process parameters of induction heating, the quenching process must be modelled to obtain realistic results concerning surface hardening depth as well as information about residual stresses and distortions of the bearing rings. A common method to model quenching processes is to determine heat transfer coefficients for the specific process depending on component surface temperature. This method was used to characterize the shower cooling process using an aqueous polymer solution of a modified polyalkylene glycol (PAG) type. A specifically designed test set-up allowed to determine the heat transfer coefficients for different distances between shower and hot specimen as well as for different impingement angles of the fluid relative to gravitation. Additionally, the calculated heat transfer coefficients were checked and corrected by FEM simulations.

Keywords: Induction hardening, shower quenching, PAG solution, heat transfer coefficients, numerical simulation
Die Wärmebehandlungssimulation des induktiven Randschichthärtens von großen Lagerringen ist eine anspruchsvolle multiphysikalische Aufgabe. Neben der Bestimmung der Material- und Prozessparameter der induktiven Erwärmung muss der Abschreckprozess modelliert werden, um realistische Ergebnisse bezüglich der Einhärtungstiefe sowie Informationen über Eigenspannungen und Verzüge der Lagerringe zu erhalten. Eine gängige Methode zur Modellierung von Abschreckprozessen ist die Bestimmung von Wärmeübergangskoeffizienten für den jeweiligen Prozess in Abhängigkeit von der Bauteiloberflächentemperatur. Diese Methode wurde zur Charakterisierung des Brausenabschreckprozesses mit einer wässrigen Polymerlösung eines modifizierten Polyalkylenglykols (PAG) verwendet. Ein speziell entwickelter Versuchsaufbau ermöglichte die Bestimmung der Wärmeübergangskoeffizienten für unterschiedliche Abstände zwischen Brause und heißer Probe sowie für unterschiedliche Auftreffwinkel des Fluids relativ zur Gravitation. Zusätzlich wurden die berechneten Wärmeübergangskoeffizienten durch FEM-Simulationen überprüft und korrigiert.

Schlüsselwörter: Induktionshärten, Duschabschrecken, PAG-Lösung, Wärmeübergangskoeffizienten, numerische Simulation

Authors/Autoren: Dipl.-Ing. Maria Kadanik, Dipl.-Ing. Lydia Burgschat, Dr.-Ing. Michael Reich, Prof. Dr.-Ing. habil. Olaf Keßler, Universität Rostock, Lehrstuhl für Werkstofftechnik, 18051 Rostock, maria.kadanik@uni-rostock.de (corresponding author/Kontakt)

Dr.-Ing. Sabine Petersen, Deutsche Großwälzlager GmbH, Marieneher Straße 17, 18069 Rostock

HOW TO CITE THIS ARTICLE: M. Kadanik et al.: Experimental Determination of Heat Transfer using a Polymer Solution Shower during Induction Hardening. HTM J. Heat Treatm. Mat. 76 (2021) 4, pp. 249-260, DOI:10.1515/htm-2021-0007

\section{Introduction}

Numerical simulations are increasingly being used by manufacturers for designing production processes. Especially complex production processes like induction surface hardening of chal-

\section{Einleitung}

Numerische Simulationen finden bei Herstellern immer mehr Beachtung bei der Auslegung von Produktionsprozessen. Insbesondere komplexe Produktionsprozesse, wie das induktive Rand-

\footnotetext{
* Reworked version of a lecture held at ECHT - Quenching and Distortion Engineering QDE 2021, 26.-18. April 2021, online
} 
lenging geometries benefit in many ways from numerical simulations in terms of process comprehension and improvement. In many cases, the complex induction surface hardening process is adjusted and improved by elaborate experiments with the expertise of experienced employees. Nevertheless, many effects and interactions of the multi physical fields are not yet fully understood. Therefore, numerical simulations of the induction hardening process offer the opportunity to understand the influence of different process parameters on the hardening results as well as an enormous potential for improvement.

One key aspect of the induction hardening process is quenching of the electromagnetically heated surface. While quenching must be fast enough to obtain a fully martensitic layer at the surface, a very rapid cooling of the surface can lead to distortion or even cracking. Shower quenching with aqueous polymer solutions offers a good compromise in terms of cooling rates to obtain a fully martensitic surface with low risk of distortion and cracking and is therefore frequently used in practice. For numerical simulation, the quenching process must be modelled as a temperature-dependent heat transfer at the surface. While shower quenching has hardly been investigated so far, the behaviour of aqueous polymer solutions in terms of immersion cooling has already been investigated by numerous authors [1-3]. Other authors try to replace the common quenching with polymer solutions by cooling with water-air spray $[4,5]$. Although in wide application for some decades, the quenching process using showers with an aqueous polymer solution has not yet been investigated in more detail. In the recent work, the quenching process is characterised by means of heat transfer coefficients using a specially designed test set-up. Investigated shower tools have been selected similar to those for induction hardening of large bearing rings.

\section{Quenching using aqueous polymer solutions in immersion cooling}

As shown by Hilder [1], aqueous polymer solutions of polyalkylene glycol (PAG) form an insulating polymer-rich film around the hot surface of the component. This happens because the polymers are insoluble in water if the separation temperature is exceeded. According to Liščić [6], the separation temperature of PAG polymer solutions ranges between $63^{\circ} \mathrm{C}$ and $85^{\circ} \mathrm{C}$. During quenching, the surface temperature of the component exceeds the separation temperature and therefore causes a separation of polymer and water. The polymer-rich layer encapsulates the component's surface and a vapour layer produced by vaporisation of the residual water. The heat transfer from the component to the quenching medium is determined by the thickness of the polymer film, which in turn is determined by the polymer type used and its concentration [6]. Furthermore, the agitation of the quenching medium and its concentration during immersion cooling and the temperature differ- schichthärten von anspruchsvollen Geometrien, profitieren in vielerlei Hinsicht von numerischen Simulationen in Bezug auf das Prozessverständnis und dessen Verbesserung. In vielen Fällen wird der komplexe Prozess des induktiven Randschichthärtens durch aufwendige Experimente mit dem Fachwissen erfahrener Mitarbeiter eingestellt und verbessert. Dennoch sind viele Effekte und Wechselwirkungen der multiphysikalischen Felder noch nicht vollständig verstanden. Daher bieten numerische Simulationen des Induktionshärtens die Möglichkeit, den Einfluss verschiedener Prozessparameter auf das Härtungsergebnis zu verstehen sowie ein enormes Verbesserungspotenzial des gesamten Prozesses.

Ein wesentlicher Aspekt des Induktionshärteprozesses ist das Abschrecken der elektromagnetisch erwärmten Oberfläche. Während das Abschrecken schnell genug erfolgen muss, um eine vollständig martensitische Schicht an der Oberfläche zu erhalten, kann eine sehr schnelle Abkühlung der Oberfläche zu Verzug oder sogar zu Rissen führen. Die Brausenabschreckung mit wässrigen Polymerlösungen bietet einen guten Kompromiss in Bezug auf die Abkühlgeschwindigkeit, um eine vollständig martensitische Oberfläche mit geringem Risiko von Verzug und Rissen zu erhalten und wird daher in der Praxis häufig eingesetzt. Für die numerische Simulation muss der Abschreckvorgang als temperaturabhängiger Wärmeübergang an der Oberfläche modelliert werden. Während die Brausenabschreckung bisher kaum im Fokus der Wissenschaft stand, ist das Verhalten wässriger Polymerlösungen im Sinne einer Tauchkühlung bereits von zahlreichen Autoren untersucht worden [1-3]. Andere Autoren versuchen, die übliche Abschreckung mit Polymerlösungen durch eine Kühlung mit Wasser-Luft-Spray zu ersetzen $[4,5]$. Obwohl seit einigen Jahrzehnten in breiter Anwendung, wurde das Abschrecken mittels Brausen mit einer wässrigen Polymerlösung noch nicht näher untersucht. In dieser Arbeit wird der Abschreckprozess anhand von Wärmeübergangskoeffizienten unter Verwendung eines speziell entwickelten Versuchsaufbaus charakterisiert. Die untersuchten Brausenwerkzeuge wurden ähnlich denen zum Induktionshärten von großen Lagerringen ausgewählt.

\section{Abschrecken mit wässrigen Polymer- lösungen bei Tauchabküihlung}

Wie von Hilder [1] gezeigt, bilden wässrige Polymerlösungen von Polyalkylenglykol (PAG) einen isolierenden, polymerreichen Film um die heiße Oberfläche des Bauteils. Dies geschieht, weil die Polymere in Wasser unlöslich sind, wenn die Separationstemperatur überschritten wird. Nach Liščić [6] liegt die Separationstemperatur von PAG-Polymerlösungen zwischen $63^{\circ} \mathrm{C}$ und $85^{\circ} \mathrm{C}$. Beim Abschrecken übersteigt die Oberflächentemperatur des Bauteils die Separationstemperatur und bewirkt somit eine Trennung von Polymer und Wasser. Die polymerreiche Schicht schließt die Bauteiloberfläche und eine durch Verdampfen des Restwassers entstandene Dampfschicht ein. Der Wärmeübergang vom Bauteil zum Abschreckmedium wird durch die Dicke des Polymerfilms bestimmt, die wiederum durch den verwendeten Polymertyp und die Konzentration des Polymers bestimmt wird [6]. Weiterhin beeinflussen die Umwälzung des Abschreckmediums während der 
ence between hot surface and quenching medium influence the thickness of the polymer film. The thickness of the polymer-rich film decreases during the quenching process [1]. The immersion of the component leads to an immediate separation of polymer and water in an encapsulating polymer-rich layer and a vapour blanket on the surface, which is formed from the vaporisation of the residual water. This insulating polymer-rich film stabilizes film boiling. When the pressure of the vapour between component surface and polymer film is high enough to break through the thinning polymer film, nucleate boiling occurs in these areas and spreads over the surface. As Waldeck et al. [2] have shown, during immersion cooling an explosive rewetting can occur repeatedly. This rewetting can be caused by an disturbance at the phase boundary and lead to a rupture of the stable film disturbance with immediate rewetting over the whole surface. The contact of the polymer solution with the still hot surface restarts the formation of a polymer-rich layer encapsulating a vapour blanket. Further cooling results in a temperature drop below the boiling point of water. Cooling just by convection alone starts when the temperature at the surface of the component falls below the separation temperature [6].

\section{Experimental test set-up}

Heat transfer coefficients can be calculated by inverse solution of the one-dimensional heat conduction problem using the finite difference method $[7,8]$. The determination of heat transfer coefficients requires the measurement of temperature-time-curves during quenching. Therefore, a test set-up must be designed to guarantee a one-dimensional heat transfer problem perpendicular to the cooled surface with temperature-time-measurements at different surface distances. Other factors to be considered are different distances between hot surface and shower outlet as well as the direction of impingement. The direction of impingement needs to be taken into account because induction hardening of large bearing rings includes quenching of surfaces with different orientations relative to gravitational force. Taking all these requirements into account, a test set-up, as shown in Figure 1, was developed. The set-up consists of an insulating quartz tube to minimize the radial heat loss of the cylindrical specimen over the lateral surface as well as a tiltable sample stage. The distance between specimen front surface and shower outlet can be varied. For realistic quenching results, a typical shower geometry with multiple jets used for induction hardening of large bearing rings has been investigated. An acrylic shield protects the specimen and the stage from the aqueous polymer solution jets to enter in the small gap between specimen and isolating quartz tube.

To gain a one-dimensional heat conduction problem with significant temperature gradients along the cylinder axis, the ratio of specimen length to diameter is chosen with a factor of 2.5 (diameter $24 \mathrm{~mm}$, length $60 \mathrm{~mm}$ ). Phase transformation during quench-
Tauchkühlung und die Temperaturdifferenz zwischen heißer Oberfläche und Abschreckmedium die Dicke des Polymerfilms. Die Dicke des polymerreichen Films nimmt während des Abschreckvorgangs ab [1]. Das Eintauchen des Bauteils führt zu einer sofortigen Trennung von Polymer und Wasser in einer umschließenden polymerreichen Schicht und einer Dampfschicht an der Oberfläche, die sich durch das Verdampfen des Restwassers bildet. Diese isolierende polymerreiche Schicht stabilisiert das Sieden der Dampfschicht. Wenn der Dampfdruck zwischen Bauteiloberfläche und Polymerfilm hoch genug ist, um den dünner werdenden Polymerfilm zu durchbrechen, kommt es in diesen Bereichen zum Blasensieden, das sich über die Oberfläche ausbreitet. Wie Waldeck et al. [2] gezeigt haben, kann es bei der Tauchkühlung wiederholt zu einer explosionsartigen Wiederbenetzung kommen. Diese Wiederbenetzung kann durch eine Störung an der Phasengrenzfläche hervorgerufen werden und zu einem Abreißen des stabilen Films mit sofortiger Wiederbenetzung der gesamten Oberfläche führen. Durch den Kontakt der Polymerlösung mit der noch heißen Oberfläche wird die Bildung einer polymerreichen Schicht, die eine Dampfschicht umschließt, wieder in Gang gesetzt. Die weitere Abkühlung führt zu einem Temperaturabfall unter den Siedepunkt von Wasser. Die Abkühlung allein durch Konvektion beginnt, wenn die Temperatur an der Oberfläche des Bauteils unter die Separationstemperatur fällt [6].

\section{Experimenteller Versuchsaufbau}

Wärmeübergangskoeffizienten können durch inverse Lösung des eindimensionalen Wärmeleitungsproblems mit der Finite-Differenzen-Methode $[7,8]$ berechnet werden. Die Bestimmung der Wärmeübergangskoeffizienten erfordert die Messung von Temperatur-Zeit-Verläufen während des Abschreckens. Daher muss ein Versuchsaufbau konzipiert werden, der ein eindimensionales Wärmeübergangsproblem senkrecht zur gekühlten Oberfläche mit Temperatur-Zeit-Messungen in verschiedenen Oberflächenabständen gewährleistet. Weitere Faktoren, die zu berücksichtigen sind, sind unterschiedliche Abstände zwischen heißer Oberfläche und Brausenauslass sowie die Richtung des Auftreffens. Die Aufprallrichtung muss berücksichtigt werden, da beim Induktionshärten von großen Lagerringen Oberflächen mit unterschiedlichen Orientierungen zur Schwerkraft abgeschreckt werden. Unter Berücksichtigung all dieser Anforderungen wurde ein Versuchsaufbau, wie in Bild 1 dargestellt, entwickelt. Der Aufbau besteht aus einem isolierenden Quarzrohr, um den radialen Wärmeverlust der zylindrischen Probe über die Mantelfläche zu minimieren sowie einem kippbaren Probentisch. Der Abstand zwischen Probenstirnfläche und Brausenauslass kann variiert werden. Um realistische Abschreckungsergebnisse zu erzielen, wurde eine typische Brausengeometrie mit mehreren Strahlen untersucht, die für das Induktionshärten von großen Lagerringen verwendet wird. Eine Acrylabschirmung schützt Probe und Probentisch davor, dass die Strahlen der wässrigen Polymerlösung in den schmalen Spalt zwischen Probe und isolierendem Quarzrohr eindringen können.

Um ein eindimensionales Wärmeleitungsproblem mit deutlichen Temperaturgradienten entlang der Zylinderachse zu erhalten, wird das Verhältnis von Probenlänge zu Durchmesser mit dem Faktor 2,5 gewählt (Durchmesser $24 \mathrm{~mm}$, Länge $60 \mathrm{~mm}$ ). Die 
Fig. 1. Developed test set-up for the determination of heat transfer coefficients during shower quenching and definition of the impingement angles

Bild 1. Entwickelter Versuchsaufbau zur Bestimmung der Wärmeübergangskoeffizienten bei der Brausenabschreckung und Definition der Auftreffwinkel

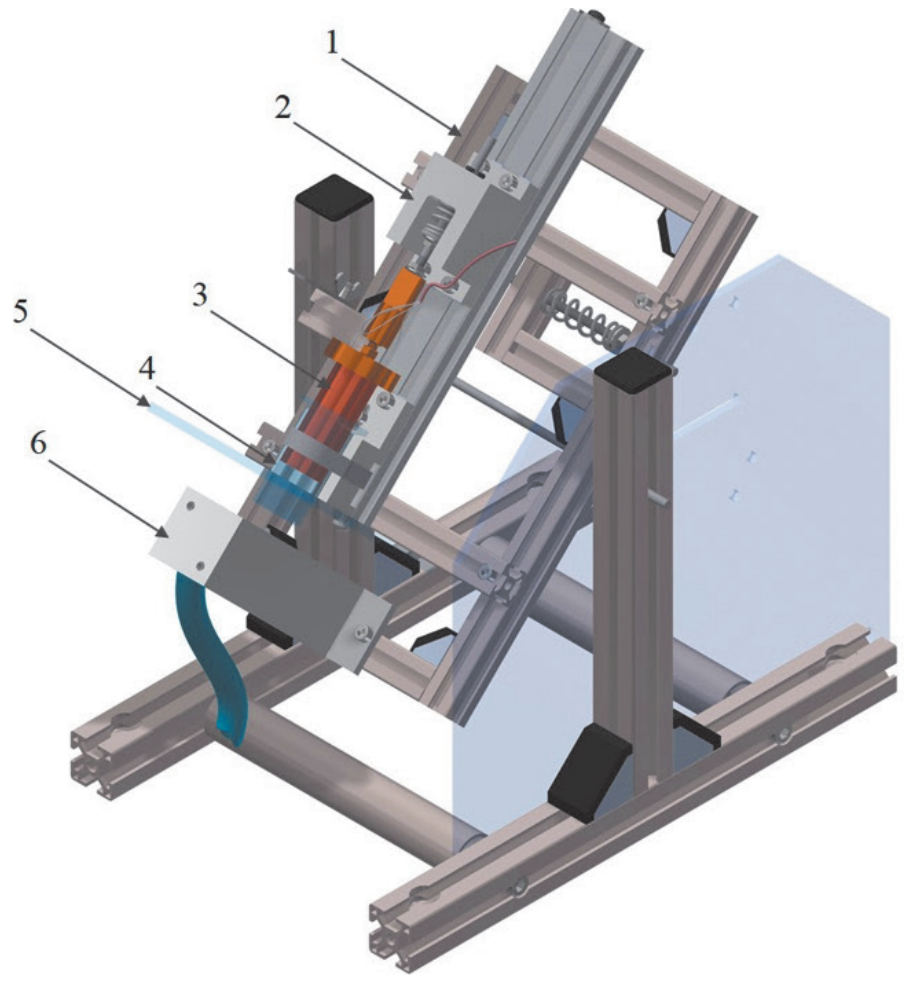

Impingement angles

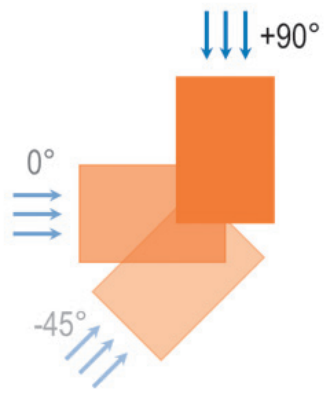

1 - tiltable sample stage

2 - sample holder with spring

3-hot specimen

4 - quartz tube

5 - acrylic shield

6 - quenching shower ing leads to heat release, which is not favourable for the determination of heat transfer coefficients. Therefore, an austenitic stainless steel AISI 304 (German steel grade X5CrNi18-10, 1.4301) showing no phase transformation in the investigated temperature range is chosen. The specimen to be quenched is equipped with boreholes on the cylinder axis in different surface distances, as shown in Figure 2, made by spark erosion technique to depict the different temperature evolutions during quenching.

After the experiments the specimens were machined starting from the quenched front surface to determine the real position of the thermocouples in the boreholes, because the inclined insertion of boreholes is prone to deviations and can lead to inaccurate positioning. Therefore, these real distance values were used for the calculation of heat transfer coefficients instead of the nominal distances indicated in Figure 2.

The steel specimens equipped with the three type $\mathrm{N}$ thermocouples in the boreholes, are heated in a chamber furnace $\mathrm{Na}$ bertherm $\mathrm{N} 11 / \mathrm{H}$ for 30 minutes at a temperature of $1100{ }^{\circ} \mathrm{C}$. The heating process as well as the quenching process are logged by the thermocouples using a TexasInstruments LabView ${ }^{\odot}$ Signal Express measurement system with a sample rate of $50 \mathrm{~Hz}$. First, the tilting sample stage is in a $-90^{\circ}$ position to ensure a fast transfer of the hot specimen from furnace to test set-up. When the specimen is fixed in the quartz tube, the sample stage is tilted to the intended measurement angle. Afterwards the quenching shower is activated until the temperature of thermocouple " 3 " with the largest distance to the surface falls below $100{ }^{\circ} \mathrm{C}$. Figure 3 shows a detailed picture of specimen and shower during the quenching process.
Phasenumwandlung beim Abschrecken führt zu einer Wärmefreisetzung, die für die Bestimmung der Wärmeübergangskoeffizienten ungünstig ist. Daher wird ein austenitischer rostfreier Stahl AISI 304 (deutsche Bezeichnung X5CrNi18-10, 1.4301) gewählt, der im untersuchten Temperaturbereich keine Phasenumwandlung zeigt. Die abzuschreckende Probe ist mit Bohrungen auf der Zylinderachse in unterschiedlichen Oberflächenabständen versehen, wie in Bild 2 dargestellt, die mittels Funkenerosionstechnik hergestellt wurden, um die unterschiedlichen Temperaturentwicklungen während des Abschreckens darzustellen.

Nach den Versuchen wurden die Proben ausgehend von der abgeschreckten Stirnfläche bearbeitet, um die reale Position der Thermoelemente in den Bohrungen zu bestimmen, da das schräge Einbringen von Bohrungen anfällig für Abweichungen ist und zu einer ungenauen Positionierung führen kann. Daher wurden diese realen Abstandswerte für die Berechnung der Wärmeübergangskoeffizienten anstelle der in Bild 2 angegebenen Nennabstände verwendet.

Die mit den drei Thermoelementen vom Typ $\mathrm{N}$ in den Bohrungen ausgestatteten Stahlproben werden in einem Nabertherm N11/H-Kammerofen für 30 Minuten bei einer Temperatur von $1100{ }^{\circ} \mathrm{C}$ erwärmt. Sowohl der Aufheizvorgang als auch der Abschreckvorgang werden von den Thermoelementen mit einem TexasInstruments LabView ${ }^{\odot}$ Signal Express Messsystem mit einer Abtastrate von $50 \mathrm{~Hz}$ aufgezeichnet. Zunächst wird der kippbare Probentisch in eine $-90^{\circ}$-Position gebracht, um einen schnellen Transfer der heißen Probe vom Ofen zum Prüfaufbau zu gewährleisten. Wenn die Probe im Quarzrohr fixiert ist, wird der Probentisch auf den vorgesehenen Messwinkel gekippt. Anschließend wird die Abschreckdusche aktiviert, bis die Temperatur des Thermoelementes „3“ mit dem größten Abstand zur Oberfläche unter 

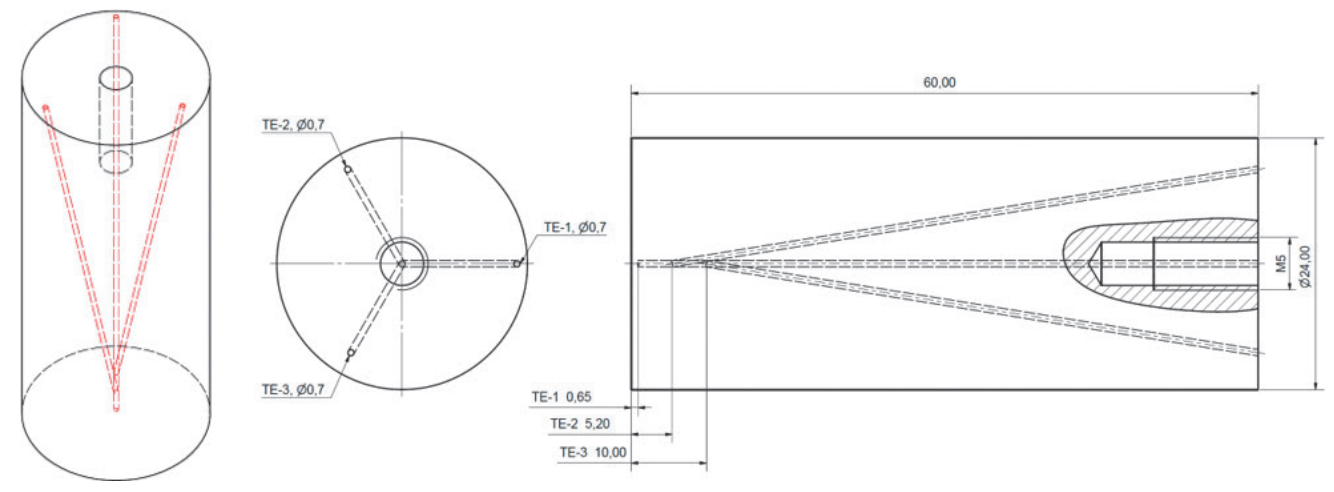

Fig. 2. Sketches of the used specimens with the boreholes for temperature measurement with thermocouples (all dimensions in $\mathrm{mm}$ )

Bild 2. Zeichnungen der verwendeten Probekörper mit den Bohrungen für die Temperaturmessung mit Thermoelementen (alle Maße in $\mathrm{mm}$ )

The polymer solution is the commercial polyalkylene glycol (PAG) based POLYQUENCH 500DSK-F (BURGDORF Abschreckhärtetechnik, Germany). The polymer concentration ranges between 18,1 weight- $\%$ and 20,3 weight- $\%$. The chosen concentration in the upper range of the recommended concentration, see datasheet [9], ensures a relatively mild quenching and can hence reduce the risk of cracking. The fluid has a temperature of $26^{\circ} \mathrm{C}$ and a shower flow rate between 10,8 1/min and 13,1 1/min. Further shower quenching experiments were conducted using tab water with a temperature of $12^{\circ} \mathrm{C}$, to compare with the polymer solution.

The surface of the stainless-steel specimen changes during the first quenching tests. As shown by Steuer [10], after a certain number of quenching tests in water, the changed surfaces no longer influence the heat transfer. Therefore, the stainless-steel specimens were each quenched several times in water before shower quenching.

\section{Calculation of heat transfer coefficients}

The heat transfer coefficients are calculated from the temperature-time-curves by a finite difference program based on

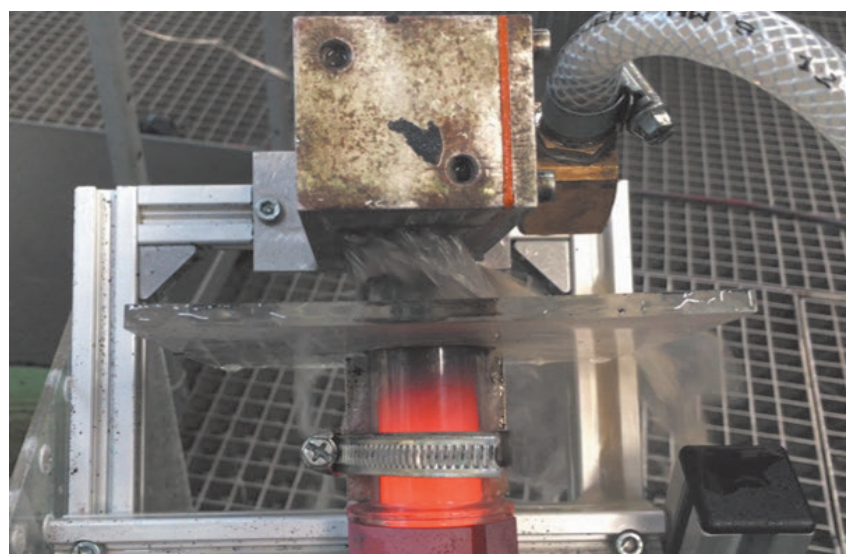

$100{ }^{\circ} \mathrm{C}$ fällt. Bild 3 zeigt eine Detailaufnahme von Probe und Brause während des Abschreckvorgangs.

Bei der Polymerlösung handelt es sich um die handelsübliche polyalkylenglykol(PAG)-basierte POLYQUENCH 500DSK-F (BURGDORF Abschreckhärtetechnik, Deutschland). Die Polymerkonzentration liegt zwischen 18,1 Gew.-\% und 20,3 Gew.-\%. Die gewählte Konzentration, die im oberen Bereich der empfohlenen Konzentration liegt (siehe Datenblatt [9]), gewährleistet eine relativ milde Abschreckung und kann somit das Risiko der Rissbildung verringern. Die Flüssigkeit hat eine Temperatur von $26^{\circ} \mathrm{C}$ und eine Brausendurchflussmenge zwischen 10,8 1/min und 13,1 1/min. Zum Vergleich mit der Polymerlösung wurden weitere Brausenabschreckungen mit Leitungswasser mit einer Temperatur von $12{ }^{\circ} \mathrm{C}$ durchgeführt.

Die Oberfläche der Edelstahlprobe verändert sich während der ersten Abschreckversuche. Wie von Steuer [10] gezeigt, beeinflussen die veränderten Oberflächen nach einer bestimmten Anzahl von Abschreckversuchen in Wasser den Wärmeübergang nicht mehr. Deshalb wurden die Edelstahlproben vor der Brausenabschreckung jeweils mehrmals in Wasser abgeschreckt.

\section{Berechnung der Wärmeübergangskoeffizienten}

Die Wärmeübergangskoeffizienten werden aus den TemperaturZeit-Kurven mit einem Finite-Differenzen-Programm in Anleh-

Fig. 3. Test set-up during shower quenching in a $0^{\circ}$ position with the shower on the top of the picture and the hot specimen in the quartz tube at the bottom (picture taken from above)

Bild 3.Versuchsaufbau während der Brausenabschreckung in $0^{\circ}$-Stellung mit der Brause oben im Bild und der heißen Probe im Quarzrohr unten (Aufnahme von oben) 
Lübben et al. [7, 8]. This is done by the inverse solution of the one-dimensional heat conduction problem. The resulting heat transfer coefficients depend on the surface temperature, which has been calculated under the assumption of no radial heat loss over the lateral surface of the cylinder. These results are shown in chapter 5 . For validation, a thermal quenching simulation of the specimen is done in MSC.MARC/MENTAT using the calculated heat transfer coefficients as a boundary condition for the front surface. For the lateral surface typical heat transfer coefficients for still air between $20 \mathrm{~W} /\left(\mathrm{m}^{2} \mathrm{~K}\right)$ and $100 \mathrm{~W} /\left(\mathrm{m}^{2} \mathrm{~K}\right)$ are assumed. The simulated temperature-time-curves for the measuring points are compared to the experimentally determined temperature-time-curves. By comparison, the heat transfer coefficients for the front surface can be corrected iteratively to account for small radial heat transfer at the lateral surface, which results in slightly lower heat transfer coefficients for the quenched surface. The best agreement of measured and simulated temperature-time-curves is found for a heat transfer coefficient of $80 \mathrm{~W} /\left(\mathrm{m}^{2} \mathrm{~K}\right)$ at the lateral surface, resulting in a slight reduction of $5 \%$ for the heat transfer coefficients at the front surface for the whole temperature range.

\section{Results of heat transfer coefficient calculations}

For every investigated quenching parameter combination up to four experiments have been performed, which are shown in Figure 4 , denoted by exp. 1-4. The calculated heat transfer coefficients for shower quenching with tab water are shown in Figure 4a. During quenching, the heat transfer coefficients start relatively low with some hundred $\mathrm{W} /\left(\mathrm{m}^{2} \mathrm{~K}\right)$ and rise with falling temperatures slowly to values between $7,000 \mathrm{~W} /\left(\mathrm{m}^{2} \mathrm{~K}\right)$ and $15,000 \mathrm{~W} /\left(\mathrm{m}^{2} \mathrm{~K}\right)$ at $200{ }^{\circ} \mathrm{C}$. Below $20{ }^{\circ} \mathrm{C}$ the heat transfer coefficients rise fast to maximum heat transfer coefficients above $25,000 \mathrm{~W} /\left(\mathrm{m}^{2} \mathrm{~K}\right)$ for a surface temperature of $55^{\circ} \mathrm{C}$. These final high values should be assessed cautiously, because low temperature gradients at the end of the experiment can cause deviations in the applied finite difference method. The heat transfer coefficients of water showers exhibit no significant dependency on impingement angle whereas an increasing distance between shower outlet and specimen's surface leads to slightly smaller heat transfer coefficients.

The calculated heat transfer coefficients using the PAG solution for different distances between specimen's surface and shower outlet as well as depending on impingement angles are shown in Figure $4 \mathrm{~b}-\mathrm{d}$. For the typically in the affiliated company used distance of $10 \mathrm{~mm}$ all impigement angles are investigated. The experiments are complemented by tests for selected parameter combinations for $8 \mathrm{~mm}$ and $12 \mathrm{~mm}$. In general, all curves show a similar development of the heat transfer coefficients during cooling. At the be- nung an Lübben et al. $[7,8]$ berechnet. Dies geschieht durch die inverse Lösung des eindimensionalen Wärmeleitungsproblems. Die resultierenden Wärmeübergangskoeffizienten hängen von der Oberflächentemperatur ab, die unter der Annahme berechnet wurde, dass kein radialer Wärmeverlust über die Mantelfläche des Zylinders auftritt. Diese Ergebnisse sind in Kapitel 5 dargestellt. Zur Validierung wird eine thermische Abschrecksimulation des Probekörpers in MSC.MARC/MENTAT durchgeführt, wobei die berechneten Wärmeübergangskoeffizienten als Randbedingung für die Stirnfläche verwendet werden. Für die Mantelfläche werden typische Wärmeübergangskoeffizienten für ruhende Luft zwischen $20 \mathrm{~W} /\left(\mathrm{m}^{2} \mathrm{~K}\right)$ und $100 \mathrm{~W} /\left(\mathrm{m}^{2} \mathrm{~K}\right)$ angenommen. Die simulierten Temperatur-Zeit-Verläufe für die Messpunkte werden mit den experimentell ermittelten Temperatur-Zeit-Kurven verglichen. Im Vergleich können die Wärmeübergangskoeffizienten für die vordere Oberfläche iterativ korrigiert werden, um den geringen radialen Wärmeübergang an der Mantelfläche zu berücksichtigen, was zu etwas niedrigeren Wärmeübergangskoeffizienten für die abgeschreckte Oberfläche führt. Die beste Übereinstimmung von gemessenen und simulierten Temperatur-Zeit-Kurven wird für einen Wärmeübergangskoeffizienten von $80 \mathrm{~W} /\left(\mathrm{m}^{2} \mathrm{~K}\right)$ an der Mantelfläche ermittelt, was zu einer leichten Reduktion von $5 \%$ für die Wärmeübergangskoeffizienten an der vorderen Oberfläche für den gesamten Temperaturbereich führt.

\section{Ergebnisse der Wärmeübergangs- koeffizientenberechnungen}

Für jede untersuchte Kombination der Abschreckparameter wurden bis zu vier Versuche durchgeführt, die in Bild 4 dargestellt sind, bezeichnet mit exp. 1-4. Die berechneten Wärmeübergangskoeffizienten für die Brausenabschreckung mit Leitungswasser sind in Bild 4a dargestellt. Beim Abschrecken beginnen die Wärmeübergangskoeffizienten relativ niedrig mit einigen hundert W/ $\left(\mathrm{m}^{2} \mathrm{~K}\right)$ und steigen mit sinkenden Temperaturen langsam auf Werte zwischen $7.000 \mathrm{~W} /\left(\mathrm{m}^{2} \mathrm{~K}\right)$ und $15.000 \mathrm{~W} /\left(\mathrm{m}^{2} \mathrm{~K}\right)$ bei $200{ }^{\circ} \mathrm{C}$ an. Unterhalb von $200^{\circ} \mathrm{C}$ steigen die Wärmeübergangskoeffizienten schnell auf maximale Wärmeübergangskoeffizienten über $25.000 \mathrm{~W} /\left(\mathrm{m}^{2} \mathrm{~K}\right)$ bei einer Oberflächentemperatur von $55^{\circ} \mathrm{C}$. Diese hohen Endwerte sind mit Vorsicht zu bewerten, da geringe Temperaturgradienten am Ende des Experiments zu Abweichungen bei der angewandten Finite-Differenzen-Methode führen können. Die Wärmeübergangskoeffizienten der Wasserbrausen zeigen keine signifikante Abhängigkeit vom Auftreffwinkel, während ein zunehmender Abstand zwischen Brausenauslass und Probenoberfläche zu etwas kleineren Wärmeübergangskoeffizienten führt.

Die mit der PAG-Lösung berechneten Wärmeübergangskoeffizienten für verschiedene Abstände zwischen Probenoberfläche und Brausenauslass sowie in Abhängigkeit vom Aufprallwinkel sind in Bild $4 \mathrm{~b}-\mathrm{d}$ dargestellt. Für den typischerweise in der Partnerfirma des Verbundprojektes verwendeten Abstand von $10 \mathrm{~mm}$ werden alle Aufprallwinkel untersucht. Ergänzt werden die Versuche durch Tests für ausgewählte Parameterkombinationen für $8 \mathrm{~mm}$ und $12 \mathrm{~mm}$. Im Allgemeinen zeigen alle Kurven eine ähnliche Entwick- 


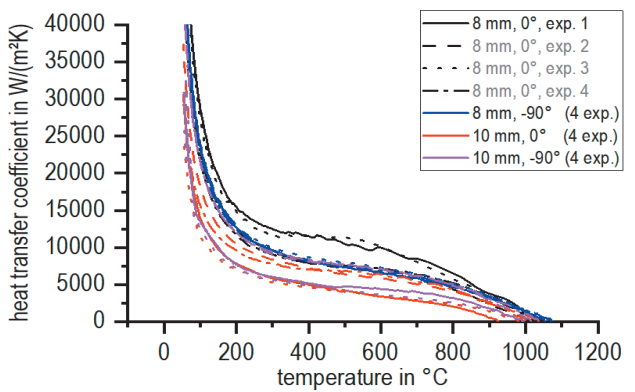

(a) water, $\mathrm{T}_{\mathrm{w}}=12^{\circ} \mathrm{C}$

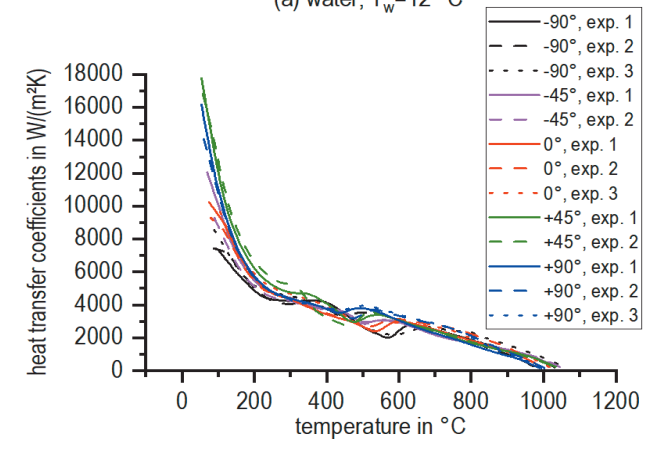

(c) PAG solution, $\mathrm{T}_{\mathrm{w}}=26^{\circ} \mathrm{C}, \mathrm{d}=10 \mathrm{~mm}$

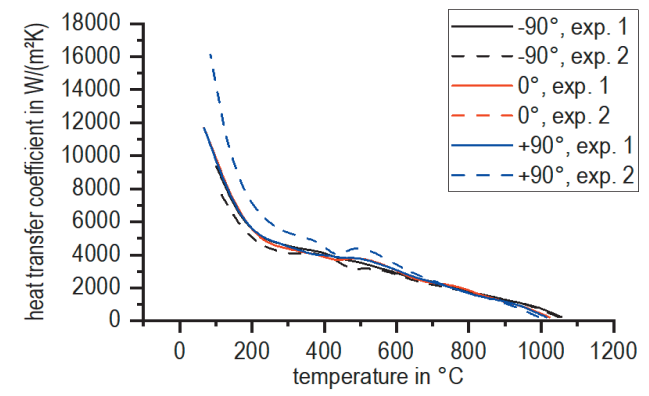

(b) PAG solution, $\mathrm{T}_{\mathrm{w}}=26^{\circ} \mathrm{C}, \mathrm{d}=8 \mathrm{~mm}$

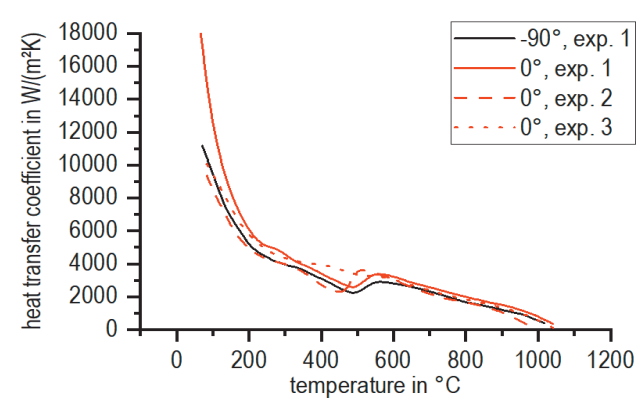

(d) PAG solution, $\mathrm{T}_{\mathrm{w}}=26^{\circ} \mathrm{C}, \mathrm{d}=12 \mathrm{~mm}$
Fig. 4. Calculated heat transfer coefficients for (a) water and PAG solution with distances between shower outlet and hot surface: (b) $8 \mathrm{~mm}$, (c) $10 \mathrm{~mm}$ and (d) $12 \mathrm{~mm}$. Consider different heat transfer coefficient scales

Bild 4. Berechnete Wärmeübergangskoeffizienten für (a) Wasser und PAG-Lösung mit Abständen zwischen Brausenauslass und heißer Oberfläche : (b) $8 \mathrm{~mm}$, (c) $10 \mathrm{~mm}$ und (d) $12 \mathrm{~mm}$. Berücksichtigen Sie die unterschiedlichen Skalen der Wärmeübergangskoeffizienten ginning of the quenching process, the heat transfer coefficients are quite small and show an increase in the temperature range between approximately $1100^{\circ} \mathrm{C}$ and $700^{\circ}$. Below the temperature of about $700^{\circ} \mathrm{C}$, for distances $10 \mathrm{~mm}$ and $12 \mathrm{~mm}$ the heat transfer coefficients for all parameter combinations run through a local minimum. The exact temperature range of the minimum differs with initial temperatures from around $675^{\circ} \mathrm{C}$ to $485^{\circ} \mathrm{C}$ and final temperatures of $585^{\circ} \mathrm{C}$ to $435^{\circ} \mathrm{C}$. The starting temperature of the local heat transfer coefficient minimum shows a slight dependence on the impingement angle, starting at higher temperatures for lower impingement angles.

For lower temperatures down to approximately $200{ }^{\circ} \mathrm{C}$ the heat transfer coefficients rise again, reaching a slope that corresponds to the slope of the heat transfer coefficients before the local minimum. Below a temperature of around $200^{\circ} \mathrm{C}$ a significant increase of the slope is observed.

An overall comparison of the heat transfer coefficients shows, that suitable heat transfer coefficients for heat treatment simulation have been determined. In the investigated range, the distance between shower outlet and hot surface does not influence the heat transfer coefficients significantly. The same was observed for the different impingement angles, except the position of the local minimum between $675^{\circ} \mathrm{C}$ and $435^{\circ} \mathrm{C}$.

\section{Discussion of heat transfer coefficients}

The heat transfer coefficients for water showers exhibit a course, which differs significantly from known heat transfer coefficients for immersion cooling in water as shown in Figure 5. The investi- lung der Wärmeübergangskoeffizienten während der Abkühlung. $\mathrm{Zu}$ Beginn des Abschreckvorgangs sind die Wärmeübergangskoeffizienten relativ niedrig und zeigen einen Anstieg im Temperaturbereich zwischen etwa $1100^{\circ} \mathrm{C}$ und $700^{\circ}$. Unterhalb der Temperatur von ca. $700^{\circ} \mathrm{C}$ durchlaufen die Wärmeübergangskoeffizienten für die Abstände $10 \mathrm{~mm}$ und $12 \mathrm{~mm}$ für alle Parameterkombinationen ein lokales Minimum. Der genaue Temperaturbereich des Minimums variiert mit Anfangstemperaturen von etwa $675^{\circ} \mathrm{C}$ bis $485^{\circ} \mathrm{C}$ und Endtemperaturen von $585^{\circ} \mathrm{C}$ bis $435^{\circ} \mathrm{C}$. Die Starttemperatur des lokalen Wärmeübergangskoeffizienten-Minimums zeigt eine leichte Abhängigkeit vom Aufprallwinkel, beginnend bei höheren Temperaturen für niedrigere Aufprallwinkel.

Für niedrigere Temperaturen bis etwa $200{ }^{\circ} \mathrm{C}$ steigen die Wärmeübergangskoeffizienten wieder an und erreichen eine Steigung, die der Steigung der Wärmeübergangskoeffizienten vor dem lokalen Minimum entspricht. Unterhalb einer Temperatur von ca. $200{ }^{\circ} \mathrm{C}$ ist ein deutlicher Anstieg der Steigung zu beobachten.

Ein Gesamtvergleich der Wärmeübergangskoeffizienten zeigt, dass geeignete Wärmeübergangskoeffizienten für die Wärmebehandlungssimulation ermittelt wurden. Im untersuchten Bereich hat der Abstand zwischen Brausenauslass und heißer Oberfläche keinen signifikanten Einfluss auf die Wärmeübergangskoeffizienten. Das Gleiche gilt für die verschiedenen Auftreffwinkel, mit Ausnahme der Lage des lokalen Minimums zwischen $675^{\circ} \mathrm{C}$ und $435^{\circ} \mathrm{C}$.

\section{Diskussion der Wärmeübergangskoeffizienten}

Die Wärmeübergangskoeffizienten für Wasserbrausen weisen einen Verlauf auf, der sich deutlich von den bekannten Wärmeübergangskoeffizienten für die Tauchkühlung in Wasser unterscheidet, wie in Bild 5 
Fig. 5. Heat transfer coefficients of water showers compared to data from water immersion (bath temperature: $60^{\circ} \mathrm{C}$, without agitation, annealing temperature $\left.840^{\circ} \mathrm{C}\right)[10]$

Bild 5.Wärmeübergangskoeffizienten von Wasserbrausen im Vergleich zu Daten von Wassertauchen (Badtemperatur: $60^{\circ} \mathrm{C}$, ohne Umwälzung, Glühtemperatur $\left.840^{\circ} \mathrm{C}\right)$ [10] gations of immersion cooling in water (bath temperature $60^{\circ} \mathrm{C}$, without agitation) done by Steuer [10] show low heat transfer coefficients of approximately $500 \mathrm{~W} /\left(\mathrm{m}^{2} \mathrm{~K}\right)$ for high temperatures, a significant rise for temperatures below $600{ }^{\circ} \mathrm{C}$ and a peak at $150{ }^{\circ} \mathrm{C}$ with about $30,000 \mathrm{~W} /\left(\mathrm{m}^{2} \mathrm{~K}\right)$. For temperatures around and below $100{ }^{\circ} \mathrm{C}$ the heat transfer coefficient shows values of approximately $1000 \mathrm{~W} /\left(\mathrm{m}^{2} \mathrm{~K}\right)$. In contrast to this curve, the determined heat transfer coefficients during shower cooling exhibit a slight increase during cooling for temperatures starting from $1100{ }^{\circ} \mathrm{C}$ to approximately $200{ }^{\circ} \mathrm{C}$ and a strong rise for temperatures below $200^{\circ} \mathrm{C}$. These completely different curves show that the cooling mechanisms probably differ for the two different quenching methods. Especially for higher temperatures the film boiling, marked by relatively low heat transfer coefficients of some hundred $\mathrm{W} /\left(\mathrm{m}^{2} \mathrm{~K}\right)$, is strongly suppressed by the impinging cold fluid.

Comparing the curves for the heat transfer of water and PAG solution (see Figure 4), it is obvious, that the heat transfer coefficients for the polymer solution are significantly lower over the whole temperature range. This corresponds to the above described mechanism to slow down the quenching process with PAG solutions compared to water quenching. The qualitative courses of the curves are similar, but the heat transfer coefficients for the polymer solution show a local minimum in a temperature range between $675^{\circ} \mathrm{C}$ and $435^{\circ} \mathrm{C}$, which is not seen for water.

Hilder [1] showed with temperature measurements and sample photographs that already an agitation of $0,5 \mathrm{~m} / \mathrm{s}$ suppresses the stable film boiling during immersion quenching using a diluted PAG solution. As shower quenching is correlated with high agitation rates, it becomes clear that there is probably no stable film boiling during shower quenching. This corresponds to the relatively high and constantly rising heat transfer coefficients for high temperatures. Nevertheless, the heat transfer coefficients are significantly lower, even for high temperatures, compared to water. This effect is probably linked to the inverse solubility of the modified PAG solution. During nucleate boiling the water of the PAG solution evaporates due to the high surface temperatures, leaving a solution with higher concentration of the polymer. The higher concentration of the polymer near the hot surface impedes liquid movement due to higher viscosity and therefore the heat transfer [6].

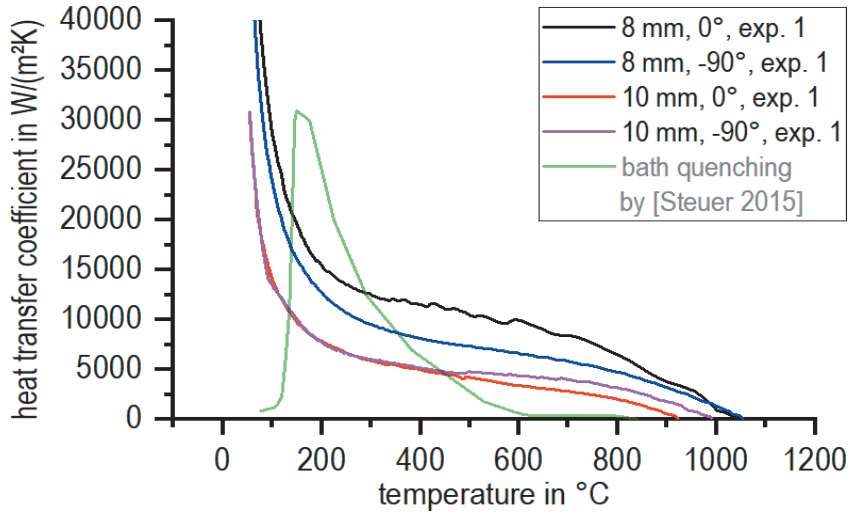

dargestellt. Die Untersuchungen zur Tauchkühlung in Wasser (Badtemperatur $60^{\circ} \mathrm{C}$, ohne Umwälzung) von Steuer [10] zeigen für hohe Temperaturen niedrige Wärmeübergangskoeffizienten von etwa $500 \mathrm{~W} /\left(\mathrm{m}^{2} \mathrm{~K}\right)$, einen deutlichen Anstieg für Temperaturen unter $600{ }^{\circ} \mathrm{C}$ und einen Peak bei $150{ }^{\circ} \mathrm{C}$ mit etwa $30.000 \mathrm{~W} /\left(\mathrm{m}^{2} \mathrm{~K}\right)$. Für Temperaturen um und unter $100{ }^{\circ} \mathrm{C}$ zeigt der Wärmeübergangskoeffizient Werte von etwa $1000 \mathrm{~W} /\left(\mathrm{m}^{2} \mathrm{~K}\right)$. Im Gegensatz zu dieser Kurve zeigen die ermittelten Wärmeübergangskoeffizienten während der Brausenabschreckung einen leichten Anstieg während der Abkühlung für Temperaturen ab $1100{ }^{\circ} \mathrm{C}$ bis ca. $200^{\circ} \mathrm{C}$ und einen starken Anstieg für Temperaturen unter $200^{\circ} \mathrm{C}$. Diese völlig unterschiedlichen Kurven zeigen, dass sich die Abkühlungsmechanismen bei den beiden $\mathrm{Ab}$ schreckmethoden wahrscheinlich unterscheiden. Insbesondere für höhere Temperaturen wird das Filmsieden, das durch relativ niedrige Wärmeübergangskoeffizienten von einigen hundert $\mathrm{W} /\left(\mathrm{m}^{2} \mathrm{~K}\right)$ gekennzeichnet ist, durch das auftreffende kalte Fluid stark unterdrückt.

Vergleicht man die Kurven für den Wärmeübergang von Wasser und PAG-Lösung (siehe Bild 4), so fällt auf, dass die Wärmeübergangskoeffizienten für die Polymerlösung über den gesamten Temperaturbereich deutlich niedriger sind. Dies entspricht dem oben beschriebenen Mechanismus zur Verlangsamung des Abschreckvorgangs mit PAG-Lösungen im Vergleich zur Wasserabschreckung. Die qualitativen Verläufe der Kurven sind ähnlich, aber die Wärmeübergangskoeffizienten für die Polymerlösung zeigen ein lokales Minimum in einem Temperaturbereich zwischen $675^{\circ} \mathrm{C}$ und $435^{\circ} \mathrm{C}$, das für Wasser nicht zu sehen ist.

Hilder [1] zeigte mit Temperaturmessungen und Probenaufnahmen, dass bereits eine Rührbewegung von $0,5 \mathrm{~m} / \mathrm{s}$ das stabile Filmsieden bei Tauchabschreckungen mit einer verdünnten PAGLösung unterdrückt. Da die Brausenabschreckung einer Abschreckung mit hohen Umwälzgeschwindigkeiten entspricht, wird deutlich, dass es bei der Brausenabschreckung wahrscheinlich kein stabiles Filmsieden gibt. Dies deckt sich mit den relativ hohen und stetig ansteigenden Wärmeübergangskoeffizienten für hohe Temperaturen. Dennoch sind die Wärmeübergangskoeffizienten auch für hohe Temperaturen im Vergleich zu Wasser deutlich geringer. Dieser Effekt hängt wahrscheinlich mit der umgekehrten Löslichkeit der modifizierten PAG-Lösung zusammen. Während des Keimsiedens verdampft das Wasser der PAG-Lösung aufgrund der hohen Oberflächentemperaturen und hinterlässt eine Lösung mit höherer Konzentration des Polymers. Die höhere Konzentrati- 


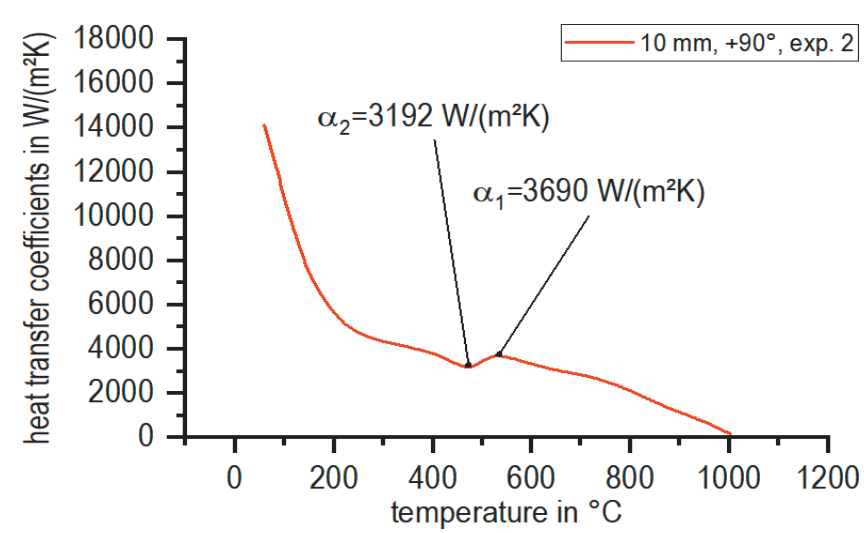

A similar effect as the local minimum in heat transfer coefficients between $675^{\circ} \mathrm{C}$ and $435^{\circ} \mathrm{C}$ has been observed in immersion cooling experiments by Waldeck et al. [2]. Their temperature-time-curves show different intensities of slowed cooling or even reheating depending on the position of thermocouples as well as depending on agitation conditions. They assume that this effect is caused by an explosive rewetting of the hot surface with a subsequent formation of a new insulating polymer-rich layer. For all heat transfer coefficient curves the local minima were characterized by a relative reduction $\Delta \alpha / \alpha_{1}$ according equation (1) and Figure 6:

$$
\frac{\Delta \alpha}{\alpha_{1}}=\frac{\alpha_{1}-\alpha_{2}}{\alpha_{1}}
$$

with $\alpha_{1}=$ local maximum of the heat transfer coefficient and $\alpha_{2}=$ local minimum of the heat transfer coefficient.

The increase of $\Delta \alpha / \alpha_{1}$ for higher distances between sample surface and shower outlet, as shown in Figure 7a, suggests that the effect is linked to the local impact of the impinging quenching fluid jets. The shower jets broaden and thereby weaken with higher distances. Additionally, the increase might as well be influenced by the impingement angle as shown in Figure $7 \mathrm{~b} . \Delta \alpha \alpha_{1}$ shows a tendency to be less pronounced for impingement angles of $+90^{\circ}$. This parameter also influences the shower jet impact, as the initial shower outlet velocity superposes with gravitational force. The relatively high scatter in the decrease of $\Delta \alpha \alpha_{1}$ can have different causes. The analysis strongly depends on the local minimum and maximum values of the heat transfer coefficient and $\Delta \alpha / \alpha_{1}$ is hence very sensitive to slight changes. As Kumar et al. [10] showed, the surface tension significantly depends on the local concentration of additives. Therefore, already small changes in the concentration of the polymer can lead to substantial changes in the surface tension and thus influence at which temperature a vapour film can form.
Fig. 6. Determination of change in heat transfer coefficients shown for an exemplary curve

Bild 6. Ermittlung der Änderung derWärmeübergangskoeffizienten anhand einer Beispielkurve

on des Polymers in der Nähe der heißen Oberfläche behindert die Flüssigkeitsbewegung aufgrund der höheren Viskosität und damit den Wärmeübergang [6].

Ein ähnlicher Effekt wie das lokale Minimum der Wärmeübergangskoeffizienten zwischen $675^{\circ} \mathrm{C}$ und $435^{\circ} \mathrm{C}$ wurde bei Tauchabschreckungsexperimenten von Waldeck et al. beobachtet [2]. Ihre Temperatur-Zeit-Kurven zeigen unterschiedliche Intensitäten der verlangsamten Abkühlung oder sogar Wiedererwärmung in Abhängigkeit von der Position der Thermoelemente sowie in Abhängigkeit von den Umwälzbedingungen. Sie vermuten, dass dieser Effekt durch eine explosionsartige Wiederbenetzung der heißen Oberfläche mit anschließender Neubildung einer isolierenden polymerreichen Schicht verursacht wird. Für alle Wärmeübergangskoeffizientenkurven wurden die lokalen Minima durch eine relative Reduktion $\Delta \alpha / \alpha_{1}$ gemäß Gleichung (1) und Bild 6 charakterisiert:

$\frac{\Delta \alpha}{\alpha_{1}}=\frac{\alpha_{1}-\alpha_{2}}{\alpha_{1}}$

mit $\alpha_{1}=$ lokales Maximum des Wärmeübergangskoeffizienten und $\alpha_{2}=$ lokales Minimum des Wärmeübergangskoeffizienten.

Die Zunahme von $\Delta \alpha / \alpha_{1}$ für höhere Abstände zwischen Probenoberfläche und Brausenauslass, wie in Bild 7a gezeigt, deutet darauf hin, dass der Effekt mit der lokalen Wirkung der auftreffenden Strahlen der Abschreckflüssigkeit zusammenhängt. Die Duschstrahlen verbreitern sich und werden dadurch bei höheren Abständen schwächer. Zusätzlich könnte der Anstieg auch durch den Auftreffwinkel beeinflusst werden, wie in Bild 7b gezeigt. $\Delta \alpha / \alpha_{1}$ zeigt eine Tendenz für Auftreffwinkel von $+90^{\circ}$ weniger ausgeprägt $\mathrm{zu}$ sein. Dieser Parameter beeinflusst auch den Aufprall der Brausenstrahlen, da sich die anfängliche Geschwindigkeit der Brausenstrahlen mit der Gravitationskraft überlagert. Die relativ große Streuung der Abnahme von $\Delta \alpha / \alpha_{1}$ kann verschiedene Ursachen haben. Die Analyse hängt stark von den lokalen Minimal- und Maximalwerten des Wärmeübergangskoeffizienten ab und $\Delta \alpha / \alpha_{1}$ ist daher sehr empfindlich gegenüber kleinen Änderungen. Wie Kumar et al. [10] zeigten, hängt die Oberflächenspannung stark von der lokalen Konzentration der Additive ab. Daher können bereits kleine Änderungen in der Konzentration des Polymers zu erheblichen Änderungen der Oberflächenspannung führen und damit beeinflussen, bei welcher Temperatur sich ein Dampffilm bilden kann. 

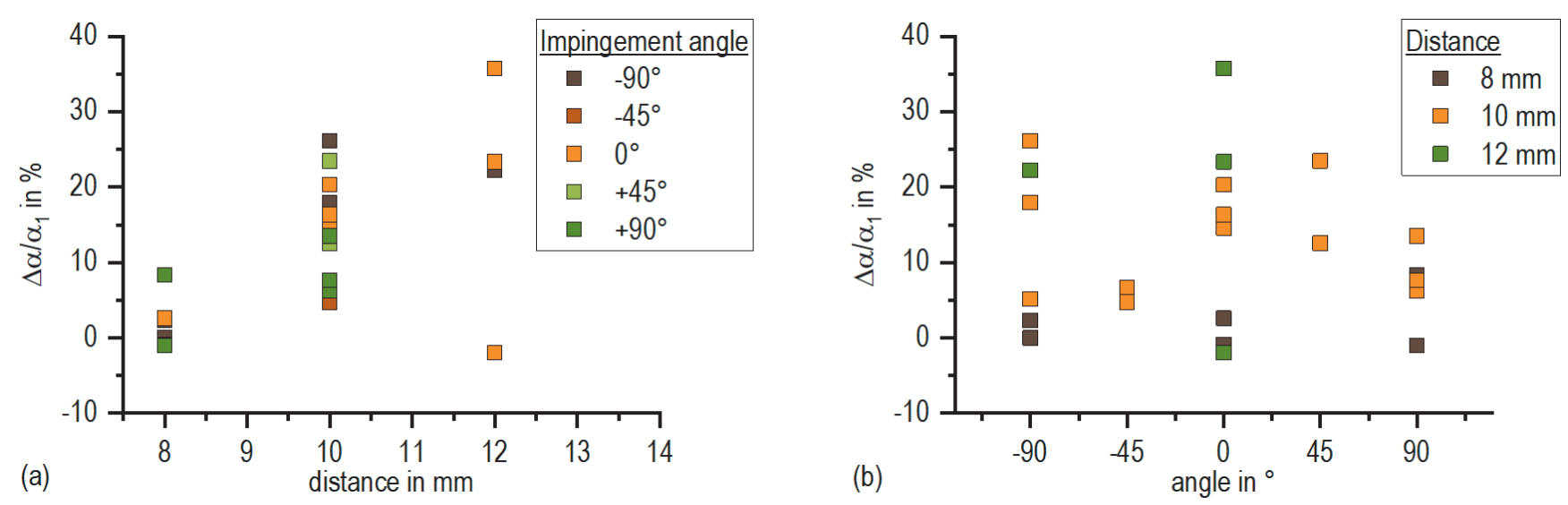

Fig. 7. Change in the heat transfer coefficients $\Delta \alpha / \alpha 1$ (a) for the different distances between shower outlet and specimen's surface, (b) for the different impingement angles

Bild 7. Änderung derWärmeübergangskoeffizienten $\Delta \alpha / \alpha 1$ (a) für die verschiedenen Abstände zwischen Brausenauslass und Probenoberfläche, (b) für die verschiedenen Auftreffwinkel

The rising heat transfer coefficients of the PAG solution for temperatures below approximately $200{ }^{\circ} \mathrm{C}$ show a similar steep slope compared to experiments with water showers. In both cases, heat transfer is dominated by strong forced convection nearly without evaporation. Resulting heat transfer coefficients of several $10,000 \mathrm{~W} /\left(\mathrm{m}^{2} \mathrm{~K}\right)$ roughly agree with those common for single impinging fluid jets [11] or immersion quenching with extreme agitation [12].

\section{Correction of calculated heat transfer coefficients}

As mentioned in chapter 4 , the heat transfer coefficients are calculated under the assumption of a one-dimensional heat transfer problem. Although the quartz tube insulates the specimen over its lateral surface, a one-dimensional heat transfer problem cannot be achieved in practice. That means, the heat transfer over the front surface is overestimated.

This effect can be corrected by numerical simulations using the FE method. In this case, the cylinder is considered as a 2D model using the axial symmetry. Starting with a constant temperature of $1100^{\circ} \mathrm{C}$ the transfer of the specimen from the furnace into the test set-up is considered with heat transfer coefficients of $180 \mathrm{~W} /\left(\mathrm{m}^{2} \mathrm{~K}\right)$ over the outer boundaries of the mesh. By applying the calculated temperature dependent heat transfer coefficients to the front surface of the specimen after the transfer the model simulates the quenching process. With a heat transfer coefficient of $10 \mathrm{~W} /\left(\mathrm{m}^{2} \mathrm{~K}\right)$ the simulated temperature-time-curves in Figure 8a show a significant deviation from the experimentally determined results especially for later times. Therefore, the heat transfer coefficient over the lateral surface must be raised combined with a reduction of the heat transfer coefficient over the front surface to account for the energy balance. Iteratively, a constant heat transfer coefficient of $80 \mathrm{~W} /$
Die ansteigenden Wärmeübergangskoeffizienten der PAG-Lösung für Temperaturen unterhalb von ca. $200{ }^{\circ} \mathrm{C}$ zeigen einen ähnlich steilen Anstieg wie bei Versuchen mit Wasserbrausen. In beiden Fällen wird der Wärmeübergang durch starke erzwungene Konvektion dominiert und die Verdampfung nahezu vollständig unterdrückt. Daraus resultierende Wärmeübergangskoeffizienten von mehreren $10.000 \mathrm{~W} /\left(\mathrm{m}^{2} \mathrm{~K}\right)$ stimmen in etwa mit denen überein, die für einzelne auftreffende Flüssigkeitsstrahlen [11] oder Tauchabschreckungen mit extremer Umwälzung [12] üblich sind.

\section{Korrektur der berechneten Wärmeübergangskoeffizienten}

Wie in Kapitel 4 erwähnt, werden die Wärmeübergangskoeffizienten unter der Annahme eines eindimensionalen Wärmeübergangsproblems berechnet. Obwohl das Quarzrohr den Prüfling über ihre Mantelfläche isoliert, kann ein eindimensionales Wärmeübergangsproblem in der Praxis nicht erreicht werden. Das heißt, der Wärmeübergang über die Stirnfläche wird überschätzt.

Dieser Effekt kann durch numerische Simulationen mit der FEMethode korrigiert werden. In diesem Fall wird der Zylinder als 2DModell unter Verwendung der Axialsymmetrie betrachtet. Ausgehend von einer konstanten Temperatur von $1100{ }^{\circ} \mathrm{C}$ wird der Transfer des Probekörpers aus dem Ofen in den Versuchsaufbau mit Wärmeübergangskoeffizienten von $180 \mathrm{~W} /\left(\mathrm{m}^{2} \mathrm{~K}\right)$ über die äußeren Grenzen des Netzes berücksichtigt. Durch Anwendung der berechneten temperaturabhängigen Wärmeübergangskoeffizienten auf die Stirnfläche der Probe nach dem Transfer simuliert das Modell den Abschreckvorgang. Bei einem Wärmeübergangskoeffizienten von $10 \mathrm{~W} /\left(\mathrm{m}^{2} \mathrm{~K}\right)$ zeigen die simulierten Temperatur-Zeit-Kurven in Bild $8 \mathrm{a}$ insbesondere für spätere Zeiten eine deutliche Abweichung von den experimentell ermittelten Ergebnissen. Daher muss der Wärmeübergangskoeffizient über die Mantelfläche erhöht werden, kombiniert mit einer Reduzierung des Wärmeübergangskoeffizienten über die Stirnfläche, um die 

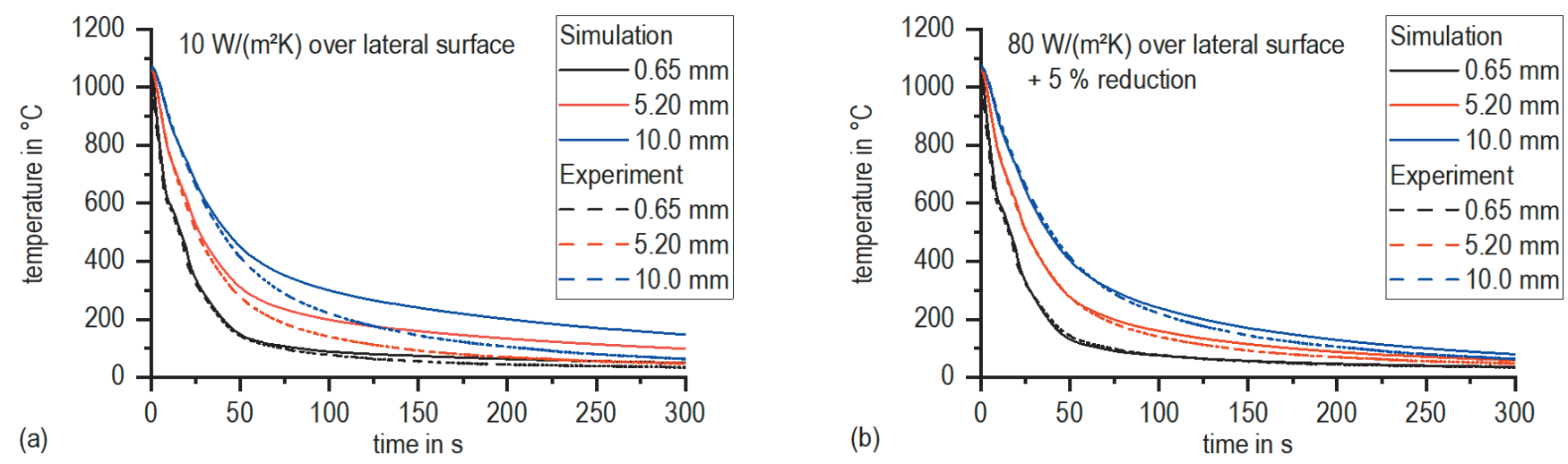

Fig. 8. Comparison of experimental results and calculated heat transfer coefficients, (a) heat transfer via lateral surface $10 \mathrm{~W} /\left(\mathrm{m}^{2} \mathrm{~K}\right)$ and

(b) heat transfer via lateral surface $80 \mathrm{~W} /\left(\mathrm{m}^{2} \mathrm{~K}\right)$ combined with $5 \%$ reduction of calculated heat transfer coefficient via front surface

Bild 8.Vergleich der experimentellen Ergebnisse und der berechneten Wärmeübergangskoeffizienten, (a) Wärmeübergang über die Mantelfläche $10 \mathrm{~W} /\left(\mathrm{m}^{2} \mathrm{~K}\right)$ und (b) Wärmeübergang über die Mantelfläche $80 \mathrm{~W} /\left(\mathrm{m}^{2} \mathrm{~K}\right)$ in Kombination mit einer 5 \%-igen Reduzierung des berechneten Wärmeübergangskoeffizienten über die Stirnfläche

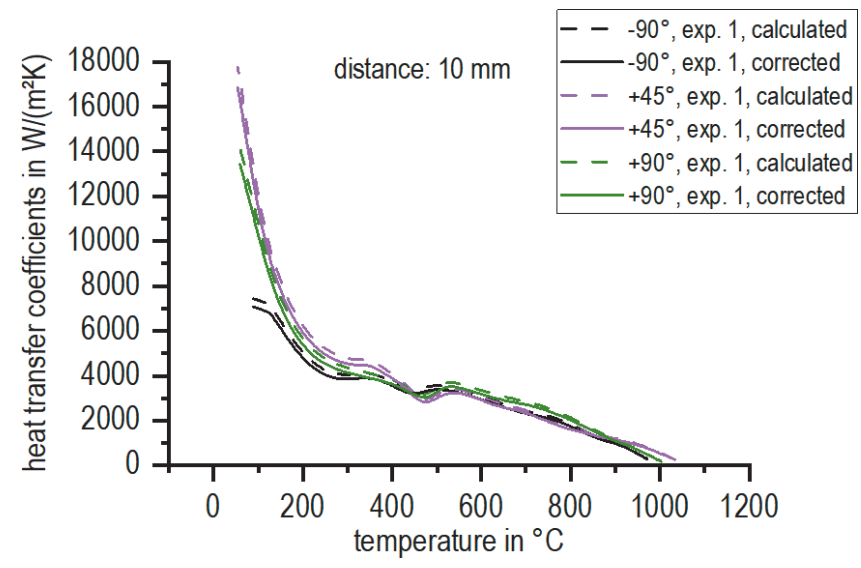

$\left(\mathrm{m}^{2} \mathrm{~K}\right)$ has been determined for the lateral surface combined with a reduction of the calculated heat transfer coefficients over the front surface by $5 \%$ for the complete temperature range. A comparison of the experimental results and the temperature-time-curves with the mentioned boundary condition in Figure $8 \mathrm{~b}$ shows a good accordance and proofs the correctness of the calculation with the inverse solution of the one-dimensional heat transfer problem.

For application in simulations, the corrected heat transfer coefficient, as shown in Figure 9, must be used to reproduce the actual quenching process correctly.

\section{Conclusion}

In this study the heat transfer coefficients for shower quenching with an aqueous PAG polymer solution as it is often used in inductive surface hardening were determined using a specifically designed test set-up. Suitable heat transfer coefficients for heat treatment simulation were calculated from the measured temperature-time-curves.
Fig. 9. Comparison of calculated and corrected heat transfer coefficients for 3 parameter combinations

Bild 9.Vergleich der berechneten und korrigierten Wärmeübergangskoeffizienten für 3 Parameterkombinationen

Energiebilanz zu erfüllen. Iterativ wurde ein konstanter Wärmeübergangskoeffizient von $80 \mathrm{~W} /\left(\mathrm{m}^{2} \mathrm{~K}\right)$ für die Mantelfläche in Kombination mit einer Reduktion der berechneten Wärmeübergangskoeffizienten über die Stirnfläche um $5 \%$ für den gesamten Temperaturbereich ermittelt. Ein Vergleich der experimentellen Ergebnisse und der Temperatur-Zeit-Kurven mit der genannten Randbedingung in Bild $8 \mathrm{~b}$ zeigt eine gute Übereinstimmung und beweist die Richtigkeit der Berechnung mit der inversen Lösung des eindimensionalen Wärmeübertragungsproblems.

Für die Anwendung in Simulationen muss der korrigierte Wärmeübergangskoeffizient, wie in Bild 9 gezeigt, verwendet werden, um den tatsächlichen Abschreckvorgang korrekt wiederzugeben.

\section{Schlussfolgerung}

In dieser Studie wurden die Wärmeübergangskoeffizienten für die Brausenabschreckung mit einer wässrigen PAG-Polymerlösung, wie sie häufig bei der induktiven Oberflächenhärtung eingesetzt wird, mit einem speziell entwickelten Versuchsaufbau ermittelt. Es wurden geeignete Wärmeübergangskoeffizienten für die Wärmebehandlungssimulation aus den gemessenen Temperatur-Zeit-Verläufen berechnet. 
The polymer solution shows lower heat transfer coefficients compared to shower quenching with water similar to the milder quenching behaviour of polymer solutions in immersion quenching. For most of the heat transfer coefficients a local minimum is observed in a temperature range between approximately $675^{\circ} \mathrm{C}$ and $435^{\circ} \mathrm{C}$. This is clearly an effect of the used polymer solution, because no such effect occurs for any parameter combination using water. It is probably linked to rewetting with subsequent formation of an insulating polymer layer.

In the investigated range, the distance between shower outlet and hot surface does not influence the heat transfer coefficients significantly. The same was found for the different impingement angles, except the position of the local minimum between $675^{\circ} \mathrm{C}$ and $435^{\circ} \mathrm{C}$.

The calculations using the FEM model show that the calculated heat transfer coefficients need to be slightly corrected before they are used as boundary conditions in simulations. Thus, the actual heat transfer coefficients can be calculated and the quenching process can be modelled correctly. This study shows that with the developed test set-up and method heat transfer coefficients can be calculated for the complete possible concentration range even for different polymer solutions. Hence, the heat transfer coefficients for applications with lower polymer concentration can be determined using the same methodology.

\section{Acknowledgement}

The authors gratefully acknowledge funding by the European Union within the European Regional Development Fund via Technologie-Beratungs-Institut, Schwerin, Germany (project TBl-V-1189-VBW-065).

\section{References}

1. Hilder, N. A.: The behaviour of Polymer Quenchants. Dissertation, Aston University, Birmingham 1988

2. Waldeck, S.; Castens, M.; Riefler, N.; Frerichs, F.; Lübben, T.; Fritsching, U.: Mechanisms and Process Control for Quenching with Aqueous Polymer Solutions. HTM J. Heat Treatm. Mat. 74 (2019) 4, pp. 238-256, DOI:10.3139/105.110387

3. Zinn, S.: Quenching of Induction Heated Steel. Induction heating and heat treatment. V. Rudnev, G. E. Totten, ASM International, Materials Park, OH, 2014. ISBN: 978-1627080125

4. Rodman, D.; Krause, C.; Nürnberger, F.; Bach, F.-W.; Haskamp, K.; Kästner, M.; Reithmeier, E.: Induction Hardening of Spur Gearwheels Made from 42CrMo4 Hardening and Tempering Steel by Employing Spray Cooling. Steel res. int. 82 (2011) 4, pp. 329-336, DOI:10.1002/srin.201000218

5. Rodman, D.; Krause, C.; Nürnberger, F.; Bach, F.-W.; Gerdes, L.; Breidenstein, B.: Investigation of the surface residual stresses in spray cooled induction hardened gearwheels. Int. J. of Mat. Res. 103 (2012) 1, pp. 73-79, DOI:10.3139/146.110622

6. Liščić, B.; Tensi, H. M.; Canale, L. C. F.; Totten, G. E.: Quenching theory and technology. CRC Press, Boca Raton, 2010, DOI:10.1201/9781420009163

7. Lübben, T.; Bomas, H. P.; Hougardy, H. P.; Mayr, P.: Beschreibung der Abschreckwirkung flüssiger Abschreckmittel am Beispiel zweier Härteöle I. HTM J. Heat Treatm. Mat. 46 (1991) 1, pp. 24-34

8. Lübben, T.; Bomas, H. P.; Hougardy, H. P.; Mayr, P.: Beschreibung der Abschreckwirkung flüssiger Abschreckmittel am Beispiel zweier Härteöle II. HTM J. Heat Treatm. Mat. 46 (1991) 3, pp. 155-170
Die Polymerlösung zeigt geringere Wärmeübergangskoeffizienten im Vergleich zur Brausenabschreckung mit Wasser, was dem milderen Abschreckverhalten von Polymerlösungen bei der Tauchabschreckung entspricht. Für die meisten der Wärmeübergangskoeffizienten wird ein lokales Minimum in einem Temperaturbereich zwischen ca. $675^{\circ} \mathrm{C}$ und $435^{\circ} \mathrm{C}$ beobachtet. Dabei handelt es sich eindeutig um einen Effekt der verwendeten Polymerlösung, da ein solcher Effekt bei keiner Parameterkombination mit Wasser auftritt. Er hängt wahrscheinlich mit der Wiederbenetzung mit anschließender Bildung einer isolierenden Polymerschicht zusammen.

Im untersuchten Bereich hat der Abstand zwischen Brausenauslass und heißer Oberfläche keinen signifikanten Einfluss auf die Wärmeübergangskoeffizienten. Das Gleiche gilt für die verschiedenen Auftreffwinkel, mit Ausnahme der Lage des lokalen Minimums zwischen $675{ }^{\circ} \mathrm{C}$ und $435^{\circ} \mathrm{C}$.

Die Berechnungen mit dem FEM-Modell zeigen, dass die berechneten Wärmeübergangskoeffizienten leicht korrigiert werden müssen, bevor sie als Randbedingungen in Simulationen verwendet werden. So können die tatsächlichen Wärmeübergangskoeffizienten berechnet und der Abschreckvorgang korrekt modelliert werden. Diese Studie zeigt, dass mit dem entwickelten Versuchsaufbau und der Methode die Wärmeübergangskoeffizienten für den gesamten möglichen Konzentrationsbereich auch für unterschiedliche Polymerlösungen berechnet werden können. Daher können die Wärmeübergangskoeffizienten für Anwendungen mit niedrigeren Polymerkonzentrationen mit der gleichen Methodik bestimmt werden.

\section{Danksagung}

Die Autoren bedanken sich für die Förderung durch die Europäische Union im Rahmen des Europäischen Fonds für regionale Entwicklung über das Technologie-Beratungs-Institut, Schwerin, Deutschland (Projekt TBl-V-1-189-VBW-065).

9. Burgdorf Osmirol Nüssle: Datenblatt POLYQUENCH 500 DSK-F, 2015

10. Steuer, R.: Ultraschallunterstütztes Flüssigkeitsabschrecken bei der Wärmebehandlung metallischer Werkstoffe. Dissertation, Universität Rostock, 2015

11. Kumar, V.; Sinha, K. N. R.; Raj, R.: Leidenfrost phenomenon during quenching in aqueous solutions: effect of evaporation-induced concentration gradients. Soft matter 16 (2020) 26, pp. 6145-6154, DOI:10.1039/d0sm00622j

12. Waldeck, S.; Woche, H.; Specht, E.; Fritsching, U.: Evaluation of heat transfer in quenching processes with impinging liquid jets. Int. J. of Thermal Sc. 134 (2018), pp. 160-167, DOI:10.1016/j.ijthermalsci.2018.08.001

13. Lübben, T.; Rath, J.; Krause, F; Hoffmann, F.; Fritsching, U.; Zoch, H. W.: Determination of heat transfer coefficient during high-speed water quenching. Int. J. Microstructure Mat. Properties 7 (2012) 2/3, 106, DOI:10.1504/IJMMP.2012. 047494

\section{Bibliography}

DOI:10.1515/htm-2021-0007

HTM J. Heat Treatm. Mat.

76 (2021) 4; page 249-260

(c) 2021 Walter de Gruyter GmbH, Berlin/Boston, Germany

ISSN 1867-2493, e-ISSN 2194-1831 